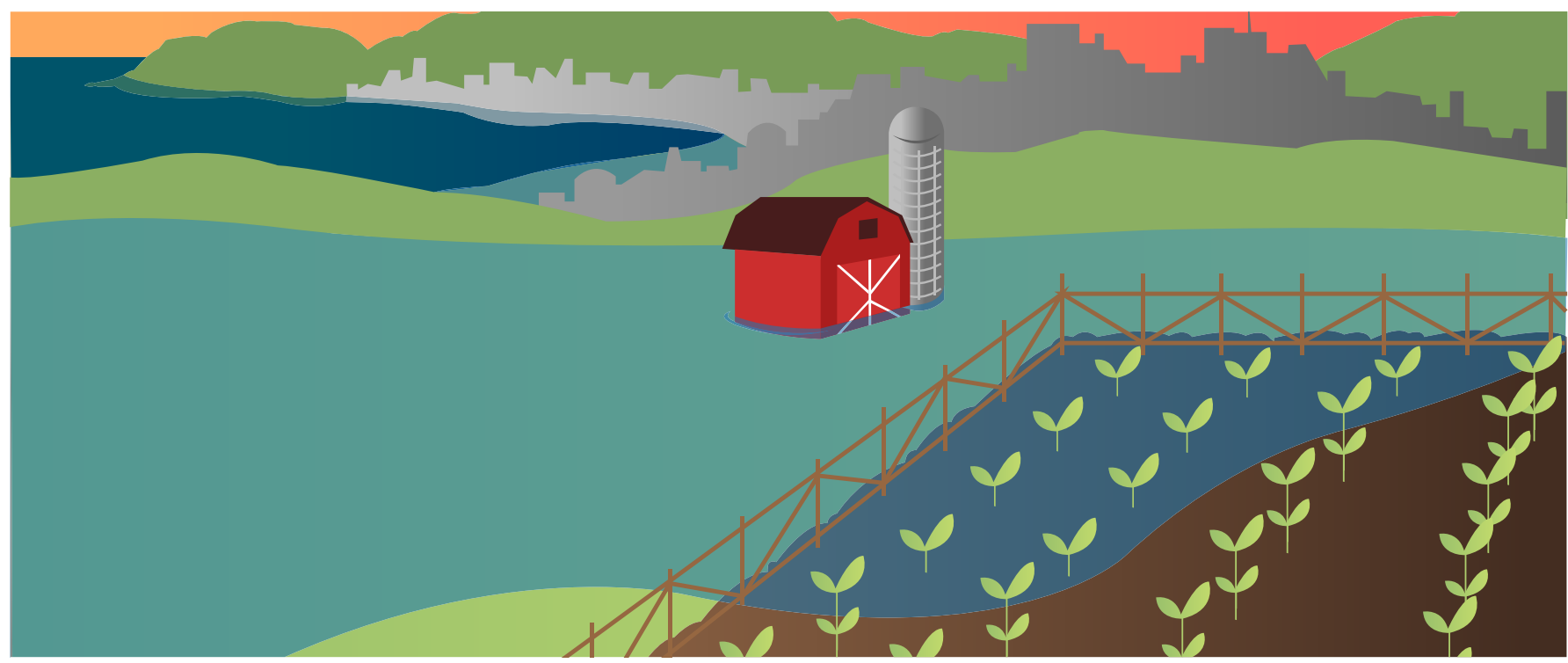

\title{
WHY SHOULD WE WORRY ABOUT SEA LEVEL
}

\section{CHANGE?}

\section{Martin J. Siegert*}

Grantham Institute and Department of Earth Science and Engineering, Imperial College London, London, United Kingdom

\section{REVIEWED BY:}

INTERNATIONAL SCHOOL OF LAUSANNE 11-12 YEARS OLD
Around 250 million people live by the coast, less than $5 \mathrm{~m}$ above the sea. Changes in sea level affect people through flooding, when water in rivers cannot flow into the ocean because the sea is too high and when seawater surges onto the land during storms. If the sea water finds its way to farms and reservoirs, it can harm our drinking water and our ability to grow crops. Because of this, knowledge of how and why sea level is changing is of importance to society.

\section{HOW MUCH IS SEA LEVEL CHANGING?}

Over the last 150 years, regular measurements have been made of the tides in ports across the world and these measurements tell us how global sea level has changed. As you can see in Figure 1, the first measurements were very simple and had some errors. But, in more recent times, the accuracy of sea level measurements has improved, and in the past few decades, we have been able to use satellites to take highly accurate measurements of the world's oceans $[1,2]$. The information gathered shows that, since about 1850, sea level has risen by about $20 \mathrm{~cm}$ around the world. The rate of sea level rise 


\section{FIGURE 1}

Global sea level change since the 1850s [1, 2].

The $y$-axis shows the sea level change in

centimeters; the $x$-axis is the date in years.

Although the early

measurements were quite simple and lacked accuracy, they reveal an upward trend in sea level (about $0.8 \mathrm{~mm}$ every year) that is greater than the margin of error. By the mid 1900s, measurements became much more accurate (the blue line) and showed the rate of sea level rise to have increased to around $2 \mathrm{~mm}$ per year. In the last few decades satellite measurements (the black line) have provided highly accurate records of sea level and showed the rate of sea level rise today stand at just over $3 \mathrm{~mm}$ each year.

\section{GLOBAL WARMING}

While climate change occurred throughout

Earth's history, the warming observed since 1850 is a consequence of the emission of greenhouse gases to the atmosphere due to the burning of coal, oil, and gas. The world is more than $1^{\circ}$ warmer than it was in 1850, and the sea level is $20 \mathrm{~cm}$ higher.

\section{ICE SHEET}

A large ice mass, which flows over hills and valleys and occupies a large portion of a continent. The world has only three major ice sheets today (Greenland, West Antarctica, and East Antarctica).

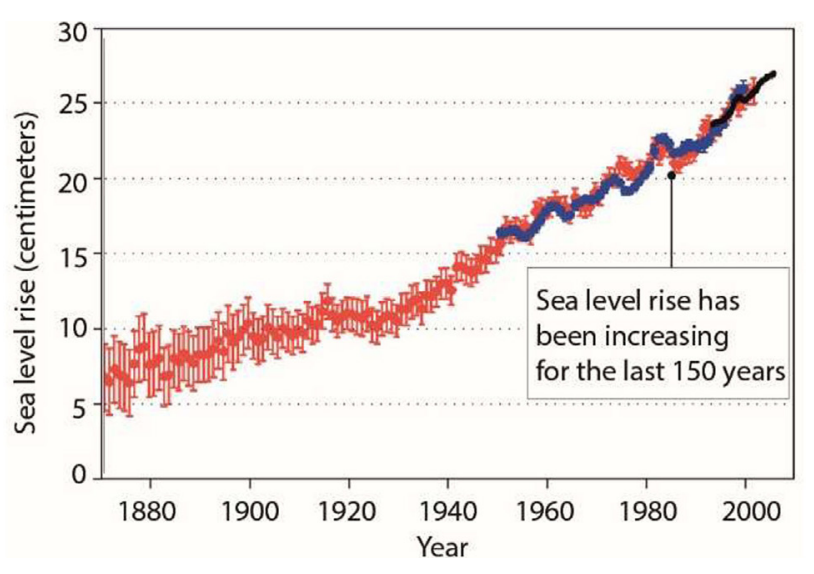

FIGURE 1

(how quickly it is rising) has also grown over this time, to just over $3 \mathrm{~mm}$ each year since the year 2000 [3].

\section{WHY DOES SEA LEVEL CHANGE?}

There are four main ways that sea level can rise: (1) Ocean warming due to global warming causes sea level to rise because water expands as it warms up; (2) melting of the world's ice sheets in Greenland and Antarctica; (3) melting of smaller glaciers around the world; and (4) decrease in the amount of water held on land, for example, in groundwater beneath the land and in reservoirs above the land. Ocean warming accounts for around half of the observed change in sea level (this is often called "thermal expansion"), with the melting of thousands of small glaciers accounting for the other half of the increase in sea level. Since the 1800s, the melting ice sheets in Antarctica and Greenland have contributed relatively little to sea level change. But, these ice sheets are starting to melt faster due to global warming and may push sea level up much more in the future.

\section{HOW MUCH COULD SEA LEVEL RISE?}

Because of global warming, the thermal expansion of the ocean and glacier melting will continue to play a role in the rise of sea level in the future [3]. If all of the planet's remaining as small glaciers were to melt, sea level would rise about $50 \mathrm{~cm}$. The amount that thermal expansion can raise sea level in the future will depend on the continued warming of sea water. The largest possible contribution to sea level rise in the future comes from the world's large ice sheets in Greenland, West Antarctica, and East Antarctica. If these ice sheets melted completely, the level of the oceans would rise about $7 \mathrm{~m}$ from the Greenland ice sheet, $5 \mathrm{~m}$ from the West Antarctic ice sheet, and $53 \mathrm{~m}$ from the East Antarctic ice sheet. This is why many glaciologists (scientists who study ice) focus on how Greenland and Antarctica are changing because of global warming. 


\section{GLACIER}

A small ice mass often located within a valley. The world has around 200,000 glaciers.

\section{ICE SHELF}

A thick (several hundred meters) region of floating ice, which receives ice from the ice sheet, and which loses ice by icebergs produced at the ice shelf edge and by melting at its underside.

\section{FIGURE 2}

A. Ice loss in Greenland through direct melting of ice, caused by warm air, and run-off of the water into the ocean.

B. Satellite measurements of ice surface elevation change in Greenland, showing the zones of major ice sheet loss (in red) - the boxes show where most melting occurs. C. Satellite measurements of ice surface elevation change in Antarctica. The red colors show where ice is being lost, and the box shows where this is happening most. D. Ice loss in Antarctica, through ocean-driven melting of the ice sheet and floating ice shelves. In Antarctica, the warm ocean flows beneath the floating ice shelf, causing it to melt from its underside, which leads to further loss of the grounded part of the ice sheet.

\section{HOW CAN MELTING ICE SHEETS CONTRIBUTE TO A RISE IN SEA LEVEL?}

As shown in Figure 2, the three ice sheets of West and East Antarctica and Greenland are each different and react differently to global warming too. For Greenland, much of the ice melting comes from warm air meeting the ice, turning the ice into water which then runs off into the ocean. In West Antarctica, the ice sheet is resting on a bed of earth that is over $2 \mathrm{~km}$ below sea level in some places, making it known as a "marine" ice sheet. As the ocean is in contact with the ice sheet edge, the warmth of the ocean water next to the ice will determine whether, and how much, the ice sheet melts. In East Antarctica, the bulk of the ice rests on land above sea level. While the intense cold of East Antarctica means that this ice sheet has likely been around for as long as 14 million years, the huge size of this ice sheet means that if even a small percentage of the ice sheet melts, there could be significant sea level effects for the whole world.

In all ice sheets, ice flows slowly from the middle to the edges, where the ice is lost to the ocean, either by melting or through the breaking of icebergs. This ice loss is balanced by snow accumulation at the surface of the ice sheet. The

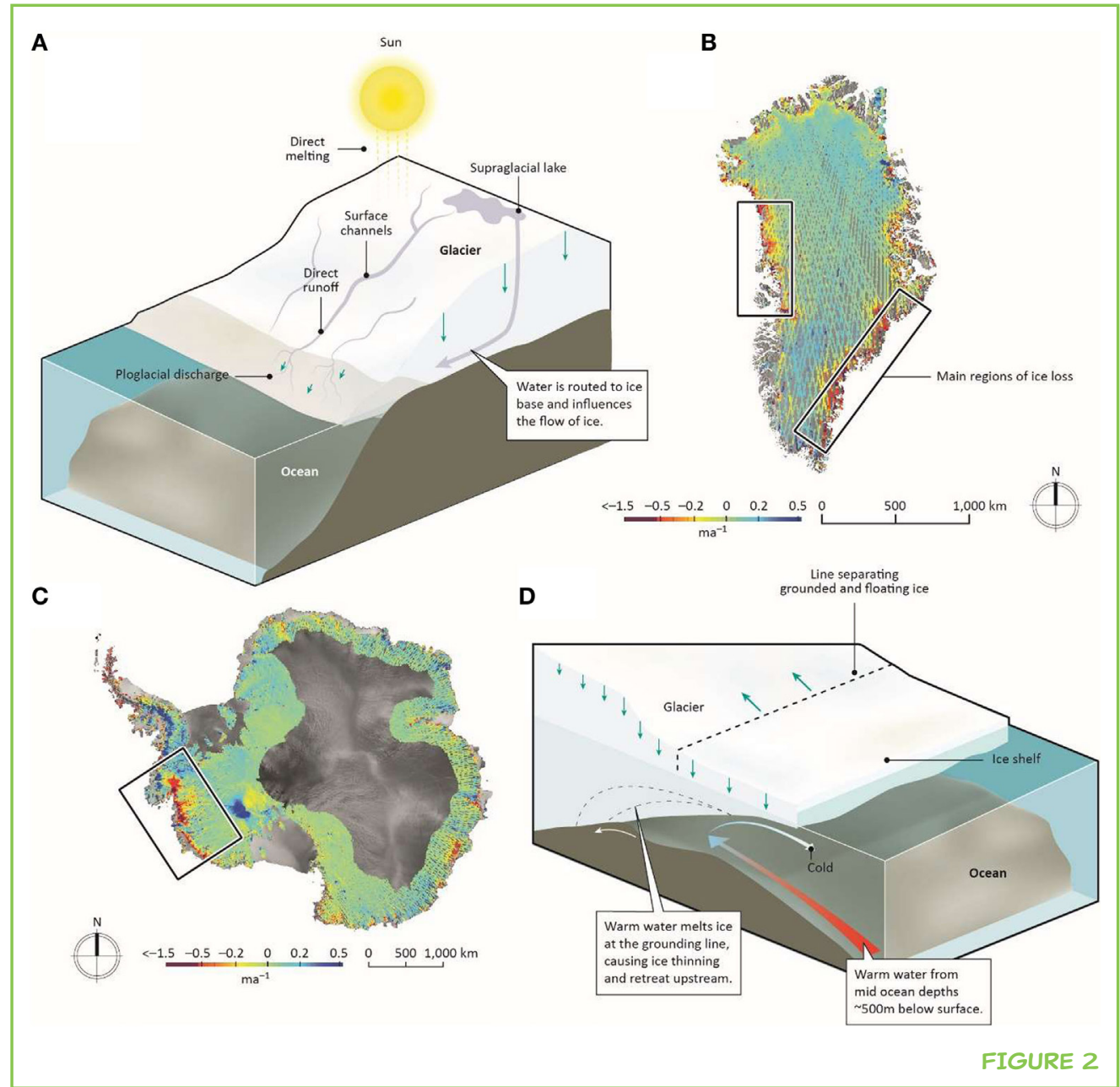




\section{SEA ICE}

A very thin (1-2 m) layer of ice that floats on the sea. Sea ice grows during the cold winter months and melts during the summer months. The amount of summer sea ice in the Arctic has been reducing in the last few decades; Antarctic sea ice change has been more variable.

\section{ICE AGE}

20,000 years ago, the world was several degrees colder than now. Ice sheets spread over North America, Scandinavia, and South America, among other places. This ice came from the ocean, and so the level of the ocean was reduced back then-by $120 \mathrm{~m}$ compared to now. difference between the ice that is lost and the amount of snow that accumulates will determine how much the ice sheet affects sea level change. However, changes to the way the ice flows, whether the flow speeds up or slows down, can also lead to rapid changes in the amount of ice that ends up in the ocean. So, changes in the way ice flows can also affect sea level change.

In West Antarctica and parts of East Antarctica, the ice that rests on land is surrounded by floating ice shelves several hundred meters thick. These floating shelves act as "buttresses" to the grounded ice, keeping it in place. So, even though melting of the floating ice shelves would not contribute directly to sea level, because they have already displaced their own weight in water, if they melt the grounded ice upstream will lose its support, which could result in increased ice flow, meaning more ice would end up in the ocean and sea level would rise.

Incidentally, ice sheets and ice shelves should not be confused with sea ice, which is a very thin (1-2 m) layer of ice over the cold polar ocean. In the Arctic, the sea ice has been shrinking for several decades as a consequence of global warming. Like ice shelves, sea ice is afloat in the water and so when it melts it makes no contribution to sea level. Its loss over several decades is an important demonstration that temperatures are increasing in the Arctic.

\section{HAS THE SEA LEVEL CHANGED IN THE PAST?}

Sea level has changed naturally in the past, mostly due to the growth and melting of large ice sheets during ice ages [4]. During the peak of the last ice age ( $\sim 20,000$ years ago), sea level was $\sim 120 \mathrm{~m}$ lower than it is today. Because of global warming that occurred between 20,000 and 10,000 years ago (which was natural and not influenced by humans), the rate of sea level rise was $1.2 \mathrm{~cm}$ per year for 10,000 years, until it leveled off to zero. During this span of time, several episodes of extra rapid sea level rise happened. For example, about 14,000 years ago, the rate of sea level rise jumped to about $3 \mathrm{~cm}$ per year, because of ice sheet melting. The last time when the climate on earth was similar to today's climate was 120,000 years ago, which is in between ice age episodes. Sea level then was at least $6 \mathrm{~m}$ higher than it is today, almost certainly because parts of the Greenland and West Antarctic ice sheets were smaller than they are now [4].

This evidence from the past is startling, because it shows that a large sea level change is possible due to global warming, and that the rate of change we see today could also be much greater.

\section{HOW IS THE ICE CHANGING TODAY?}

Since the early 1990s, satellites have been able to measure the level of the ocean and the surfaces of the ice sheets [2]. 
The satellites revealed that the world's ice sheets are losing mass in different ways. For Greenland, the southern half of the ice sheet is experiencing ice loss through surface melting due to global warming. In East Antarctica, a few regions at the ice edge are experiencing ice loss because of the warm ocean, but this is not at significant levels yet. The largest and most worrisome changes have been measured in West Antarctica. Here, in the last 20 years, ocean warmth has caused the edges of several glaciers to retreat by tens of kilometers. Some scientists believe that the West Antarctic ice sheet has started to break up [5].

Satellite measurements have also allowed us to measure the sudden disintegration of ice shelves across parts of Antarctica. Several of these have collapsed very quickly (within a few days) over the past 20 years, with the immediate effect of increasing the flow of ice into the ocean.

\section{IS GLOBAL WARMING, CAUSED BY HUMANS, RESPONSIBLE FOR THE ICE SHEET CHANGES?}

The changes observed in Greenland are almost certainly the result of global warming, with increased air temperatures melting the snow and ice. Thermal expansion of the ocean and melting of small glaciers will also occur because of global warming. The changes observed in Antarctica cannot be as easily linked to humans, however. The ocean water responsible for Antarctic ice loss probably warmed up several hundred years ago. However, the transfer of ocean warmth to the ice is the result of ocean currents, which may have changed recently due to changes in atmospheric conditions, such as wind direction. A computer model predicts that ocean currents may change in an important region of West Antarctica later this century, because of global warming due to human activities [6]. This change in ocean currents might lead to large parts of the West Antarctic ice sheet to melt more than now, due to warmer water in contact with the ice.

The rate at which the ice shelves are melting in several regions of Antarctica appears to be linked to modern global warming. If warming continues, ice shelves on the whole continent may also become vulnerable. This worries scientists because the loss of the largest ice shelves in Antarctica would mean that the West Antarctic ice sheet could be exposed to warmer ocean water and begin to melt as well.

\section{HOW WILL SEA LEVEL CHANGE IN THE FUTURE?}

Because of the rise in sea level that we have seen in the recent past, and because of global warming, scientists are pretty certain that sea level will continue to rise over the coming decades, as glaciers and ice sheets melt and as thermal expansion of ocean water occurs. 
In 2013, a report by a group called the Intergovernmental Panel on Climate Change (IPCC) stated that, under a "business as usual" situation (meaning that we keep burning fossils fuels in the future as we do today), the world's ice sheets are likely to contribute between 3.5 and $36.8 \mathrm{~cm}$ to sea level by 2100 . This, added to sea level rise through thermal expansion of the warmer sea water and glacier melting, means that in 2100 , sea level may be around $1 \mathrm{~m}$ higher than it is today.

The rate of sea level rise is also likely to increase by the end of this century. The IPCC concluded that the "business as usual" scenario will lead to an increase in the rate of change to between 0.7 and $1.6 \mathrm{~cm}$ per year by 2100 . These values are similar to the rate of sea level rise during the end of the last ice age. Even if we do reduce our greenhouse gas emissions to zero during the next few decades, the minimum sea level rise expected by 2100 will be about $40 \mathrm{~cm}$.

\section{HOW WILL SEA LEVEL RISE AFFECT THE COUNTRIES OF THE WORLD?}

The effect of ice sheet melting on sea level is different across the world [7].

So, when the sea level rises, people will be affected in different ways, depending on where they live. The UK is used to occasionally dealing with rising sea level for short periods of time, particularly when there are storms at the same time as when the tides higher than usual. If the IPCC predictions are correct, we must consider the possible increase in sea level on top of natural tidal surges. This will cause dangerously high tides to occur more often in the coming decades, and these future tides might be more destructive than we are used to.

In farming regions near the coast, seawater flooding on land can contaminate the soils with salt, making them less able to support the growth of crops. The salty water may also get into underground stores of fresh water (known as groundwater), which is the source of important drinking water and also for farmers to grow crops.

In coastal cities, sea level rise will cause more flooding to houses, businesses, and while it may seem sensible to consider moving cities away from harmful floods, especially as we know it will likely happen in the future, our cities cost so much to develop that we are more likely to simply try to protect them from rising sea levels. A vision of our cities near the sea involves them with walls facing the ocean several meters high, with the street level of the cities themselves being below the level of the ever rising sea.

\section{SUMMARY}

Sea level rise has been measured across the world since 1850. The world's oceans are now $20 \mathrm{~cm}$ higher than they were back then. This is due to 
global warming caused by greenhouse gas emissions from the burning of coal, oil, and gas. The change since 1850 is small compared to sea level changes that occurred further back in time, however. During the ice age 20,000 years ago, sea level was $120 \mathrm{~m}$ lower than it is today. This shows us two things (1) that substantial changes to sea level are possible and (2) when the climate warms, the ice melts and sea level goes up. In the future, sea level will continue to rise, possibly by as much as $1 \mathrm{~m}$ by the end of this century, if we do not reduce our greenhouse gas emissions. Such change poses great problems for the 250 million people who live close to the sea. It will affect our ability to grow crops in coastal farms, make it difficult to maintain the quality of drinking water, and will alter the way we live in and develop our cities.

\section{REFERENCES}

1. Church, J. A., and White, N. J. 2006. A 20th century acceleration in global sea-level rise. Geophys. Res. Lett. 33:L01602. doi:10.1029/2005GL024826

2. Church, J. A., Clark, P. U., Cazenave, A., Gregory, J. M., Jevrejeva, S., Levermann, A., et al. 2013. Chapter 13: Sea level change. In Climate Change 2013: The Physical Science Basis. Contribution of Working Group I to the Fifth Assessment Report of the Intergovernmental Panel on Climate Change, eds T. F. Stocker, D. Qin, G.-K. Plattner, M. Tignor, S. K. Allen, and J. Boschung, et al. Cambridge, United Kingdom, New York, NY, USA: Cambridge University Press. 1137-216.

3. Hay, C. C., Morrow, E., Kopp, R. E., and Mitrovica, J. X. 2015. Probabilistic reanalysis of twentieth-century sea-level rise. Nature 517:481-4. doi:10.1038/ nature14093

4. Siegert, M. J. 2001. Ice Sheets and Late Quaternary Environmental Change. Chichester, UK: John Wiley. 231.

5. Joughin, I., Smith, B. E., and Medley, B. 2014. Marine ice sheet collapse potentially under way for the Thwaites Glacier basin, West Antarctica. Science 344:735-8. doi:10.1126/science.1249055

6. Hellmer, H. H., Kauker, F., Timmermann, R., Determann, J., and Rae, J. 2012. Twenty-first-century warming of a large Antarctic ice-shelf cavity by a redirected coastal current. Nature 485:225-8. doi:10.1038/nature11064

7. The Ice2Sea Consortium. 2013. From Ice to High Seas: Sea-Level Rise and European Coastlines. Cambridge, United Kingdom.

SUBMITTED: 22 November 2016; ACCEPTED: 14 July 2017; PUBLISHED ONLINE: 31 July 2017.

EDITED BY: Berend Smit, École Polytechnique Fédérale de Lausanne, Switzerland CITATION: Siegert MJ (2017) Why Should We Worry About Sea Level Change? Front. Young Minds 5:41. doi:10.3389/frym.2017.00041 
CONFLICT OF INTEREST STATEMENT: The author declares that the research was conducted in the absence of any commercial or financial relationships that could be construed as a potential conflict of interest.

COPYRIGHT (C) 2017 Siegert. This is an open-access article distributed under the terms of the Creative Commons Attribution License (CC BY). The use, distribution or reproduction in other forums is permitted, provided the original author(s) or licensor are credited and that the original publication in this journal is cited, in accordance with accepted academic practice. No use, distribution or reproduction is permitted which does not comply with these terms.

\section{REVIEWED BY}

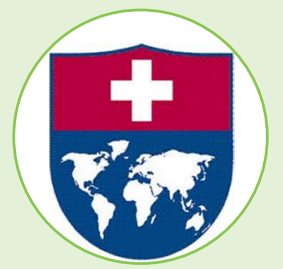

\section{INTERNATIONAL SCHOOL OF LAUSANNE, 11-12 YEARS OLD}

Found in 1962, the International School of Lausanne is a non-profit, English-language IB World School situated in the heart of the Lac Léman region of Switzerland. We welcome students from 3 to 18 years of age, and offer a range of programs and activities designed to develop the unique potential of our students. We celebrate excellence in all its forms, with a well-balanced variety of athletic, creative, and academic opportunities.

\section{AUTHOR}

\section{MARTIN J. SIEGERT}

Martin's research involves using instruments on aircraft to "see through" the ice in Antarctica to the land that lies beneath, where mountains, valleys rivers, and lakes have been discovered. He has visited Antarctica three times, and is involved in several projects with colleagues in the US, China, and Australia, among others. *m.siegert@imperial.ac.uk 